\title{
Simultaneous identification of Mycoplasma gallisepticum and Mycoplasma synoviae by duplex PCR assay.
}

\author{
Malekhoseini $\mathbf{G}^{1}$, Pourbakhsh $\mathrm{SA}^{2^{*}}$, Homayounimehr $\mathrm{AR}^{3}$, Zolfeghari $\mathrm{MR}^{1}$, Ashtari $\mathrm{A}^{2}$ and Abtin \\ $\mathbf{A R}^{2}$ \\ ${ }^{1}$ Islamic Azad University, Qom Branch, Qom, Iran \\ ${ }^{2}$ Mycoplasma Reference Laboratory, Razi Vaccine and Serum Research Institute, Karaj, Iran \\ ${ }^{3}$ Symoorgh Avian Special Clinic, Tehran, Iran
}

\begin{abstract}
Mycoplasma gallisepticum (M.G) and Mycoplasma synoviae (M.S) have recognized as common respiratory pathogens especially in chickens cause a lots of economic losses in poultry industries. The aim of this study was development and validation of duplex Polymerase Chain Reaction (PCR) for simultaneous detection of MG and MS. A total of 50 samples from tracheas, lungs and air sacs were taken from commercial broiler chicken farms in Iran. The samples were cultured in PPLO broth supplemented for M.S and M.G isolation and bacteria DNA were extracted by phenol/chloroform. The conserved region of $16 S$ rRNA gene was applied for the detection of Mycoplasma genus in $163 \mathrm{bp}$ fragment and MG in $183 \mathrm{bp}$ fragment and vlhA gene for detection of MS in $350 \mathrm{bp}$ fragment. Then duplex PCR amplified the conserved region of $16 S \mathrm{rRNA}$ and vlhA genes was applied for detection of MG and MS. 20 samples in Mycoplasma genus, 7 samples in MG and MS were positive in the single PCR whereas 3 samples simultaneously MG and MS were positive in the duplex PCR method. The results showed that duplex PCR was successful to simultaneous identification of MG and MS and suggested that duplex PCR is more rapid and inexpensive method than the single PCR for detection of MG and MS.
\end{abstract}

Keywords: Mycoplasma synoviae, Mycoplasma gallisepticum, Broiler chicken, $16 S$ rRNA, vlhA, Duplex polymerase chain reaction.

Accepted on March 27, 2017

\section{Introduction}

Avian Mycoplasmosis is caused by several pathogenic Mycoplasmas such as Mycoplasma synoviae (M.S) and Mycoplasma gallisepticum (M.G) which have recognized as common respiratory pathogens especially in chickens [1]. MG is commonly known as "chronic respiratory disease" in chickens, characterized by rhinitis, sinusitis, and conjunctivitis [2]. MS occurs most frequently as a subclinical upper respiratory infection but may result in air sacculitis and synovitis in chickens [3]. Air sac disease" describes a severe airsacculitis that is the result of $\mathrm{MG}$ or $\mathrm{MS}$ infection complicated by a respiratory virus infection (e.g. infectious bronchitis or Newcastle disease) and usually Escherichia coli [2]. MS and MG are one of the major worldwide pathogen that cause of serious economic loses in the worldwide poultry industry. MG and MS can infect the embryo and subsequently produce infected progeny [4]. Lameness and respiratory disorder caused from MS infection result in decreased growth rate and loss of egg production and causing economic loss in intensive production [5]. Air sacculitis in chickens or turkeys that result of the MG infection, with or without complicating pathogens, causes increased condemnations at processing. Economic losses from condemnations or downgrading of carcasses, reduced feed and egg production efficiency, and increased medication costs are additional factors that make this one of the costliest disease prolems confronting commercial poultry production worldwide [2]. Existence of the MG or MS can be confirmed by isolation of the organism in a cell-free medium or by detection its DNA directly in infected tissues or swab samples. Serological tests are also widely used for diagnosing of MG and MS. When results are equivocal the birds are usually resample, although chicken embryos or chickens may be inoculated with suspect material [1]. Attempts to differentiate between these two major avian Mycoplasmas by using molecular methods, such as PCR tests, were mainly based on the 16S rRNA gene [6-8]. Also in Iran the workers had been used $16 S r R N A$ gene for phylogenetic analysis of Mycoplasma Synoviae analysis [9]. However, it often required additional steps, such as restriction fragment length analysis [10] or hybridization with species-specific probes [7]. In addition, these analyses resulted in concomitant amplification of unrelated bacterial DNA, making this approach useless for the testing of clinical material [11]. A duplex PCR was developed and optimized to simultaneous detection and differentiation of MG and MS. Duplex PCR is another different PCR which could simultaneous amplification of many targets of interest in one reaction by using more than one pair of primers. Since its first description in 1988 by Chamberlain et 
Citation: Malekhoseini G, Pourbakhsh SA, Homayounimehr AR, Zolfeghari MR, Ashtari A, Abtin AR. Simultaneous identification of Mycoplasma gallisepticum and Mycoplasma synoviae by duplex PCR assay. Immunol Case Rep 2017;1(1):12-16.

al. this method has been apply in many areas where testing DNA, including analyses of deletions, mutations, and polymorphisms, or quantitative assays and reverse transcription PCR [12]. Typically, it is used for genotyping applications where simultaneous analysis of multiple markers is required, detection of pathogens or genetically modified organisms (GMOs). There are few works about duplex PCR identification between MG and MS. Sprygin et al. used duplex real-time TaqMan PCR assay with an internal control for the detection of MG and MS in clinical samples from commercial and backyard poultry [13]. Mardassi et al. used duplex PCR to differentiate between MS and MG on the basis of conserved species-specific sequences of their hemagglutinin genes. Two PCR for detection MG and MS could be replaced with duplex PCR in a single reaction and, therefore this technique is more rapid and inexpensive method than the single PCR for detection of $\mathrm{MG}$ and MS. The aim of this study was stimulation identification of MG and MS by duplex PCR assay in the suspected samples. According to our knowledge this is 1st study on MG and MS duplex PCR in Middle East.

\section{Materials and Methods}

\section{Sampling and cultures}

Samples were collected from 4 main provinces of Iranian commercial broiler chicken farms. Most of the samples were obtained from flocks with clinical signs of a probably infection by Mycoplasma spp. (MG, MS). Taking 50 samples included air sac, choanal-cleft and tracheal swabs from flocks. Then aliquot of $0.5 \mathrm{ml}$ was removed to a $1.5 \mathrm{ml}$ tube for the DNA extraction. After filtering by 0.45 filters, $0.3 \mathrm{ml}$ sample was taken for broth culture. PPLO broth and PPLO agar medium (BBL). Broth and agar media were incubated under microaerophilic condition with $98 \%$ relative humidity and checked for colour changes of broth two passages.

\section{Extraction of genomic DNA}

DNA was extracted from samples using a previously described method by Pourbakhsh et al. with some modifications [14].

Single PCR amplification with specific primer. In this study 3 published primers sets were used for the specific detection of genus and species of MS and MG. For genus Mycoplasma as follow:

\section{M1F: 5'-GCTGCGGTGAATACGTTCT-3'}

\section{M1R: 5'-TCCCCACGTTCTCGTAGGG-3'}

The 163 bp fragments were amplified [15]. The PCR mix was performed for Mycoplassma genus in a total volume of $25 \mu \mathrm{l}$ per sample, containing $2.5 \mu \mathrm{l}$ of $10 \mathrm{X}$ PCR buffer (Roch Diagnostics-corporation, Indianapolis, USA), $4 \mu \mathrm{l}$ of $25 \mathrm{mM}$ $\mathrm{MgCl} 2,0.5 \mu \mathrm{l}$ of $10 \mathrm{mM}$ dNTPs, $0.1+0.1 \mu \mathrm{l}$ each primer, $0.5 \mathrm{U}$ Taq DNA polymerase (Roch Diagnostics-Corporation Indianapolis, USA) (Figure 1a). Consequently $15.3 \mu \mathrm{l}$ of deionized distilled water and $2 \mu \mathrm{l}$ of extracted DNA as template were carried out.

In MS strain as follow:

\section{MSF: 5'-TACTATTAGCAGCTAGTGC-3'}

\section{MSR: 5 '- AGTAACCGATCCGCTTAAT-3'}

The $350 \mathrm{bp}$ fragments of MS $v l h A$ gene were amplified [16]. Then PCR mix was performed for genes positive samples for MS [total volume of $25 \mu \mathrm{l}$ per sample, containing $2.5 \mu \mathrm{l}$ of 10 X PCR buffer $4 \mu \mathrm{l}$ of $25 \mathrm{mM} \mathrm{MgCl} 2,0.3 \mu \mathrm{l}$ of $10 \mathrm{mM}$ dNTPs, $0.3+0.3 \mu 1$ each primer, $1 \mathrm{U}$ Taq DNA polymerase (Figure $1 \mathrm{~b}$ ).

In MG strain as follow:

\section{MG13F: 5'- GAGCTAATCTGTAAAGTTGGTC-3' \\ MG14R: 5'-GCTTCCTTG CGGTTAG CAAC -3'}

The 183 bp fragments of MG 16SrRNA gene were amplified [17]. PCR mix was performed for MG [total volume of $25 \mu \mathrm{l}$ per sample, containing $2.5 \mu \mathrm{l}$ of $10 \mathrm{X}$ PCR buffer $4 \mu \mathrm{l}$ of 25 $\mathrm{mM} \mathrm{MgCl} 2,0.3 \mu \mathrm{l}$ of $10 \mathrm{mM}$ dNTPs, $0.1+0.1 \mu \mathrm{l}$ each primer, 1.2U Taq DNA polymerase. Consequently $15.3 \mu$ of deionized distilled water and $2 \mu \mathrm{l}$ of extracted DNA as template were carried out (Figure 1c).

Duplex PCR was developed for the simultaneous detection of the two major avian Mycoplasma species from field isolates. The master mix was performed for duplex MG MS PCR in a total volume of $50 \mu \mathrm{l}$ per sample, containing $5.00 \mu \mathrm{l}$ of $10 \mathrm{X}$ PCR buffer, $4 \mu \mathrm{l}$ of $25 \mathrm{mM} \mathrm{MgCl} 21.00 \mu \mathrm{l}$ of $10 \mathrm{mM}$ dNTPs, $0.6+0.6 \mu \mathrm{l}$ each primer (MG and MS), 0.5U Taq DNA polymerase (Figure 1d).

Consequently $15.3 \mu \mathrm{l}$ of deionized distilled water and $2 \mu \mathrm{l}$ of extracted DNA as template was carried out. Visualization of amplified products have done by UV illumination after electrophoresis $(1 \%$ agarose gel in $1 \times$ Tris-acetic acid-EDTA (TAE) buffer) and ethidium bromide staining.

\section{Results}

A batch of 50 samples included air sac, choanal cleft and tracheal samples from flocks analyzed simultaneously by MS PCR and MG-PCR and MG and MS duplex PCR (DPCR). From 50 samples, 20 of them were positive in Mycoplasma genus. These 20 samples were considered separately MS and MG primers for diagnosing Mycoplasma species, from 20 sample, 7 samples were infected with MG, 7 samples were positive in MS and 3 samples were infected with both of the MG and MS (Tables 1 and 2). Duplex PCR reactions can be broadly divided in two categories:

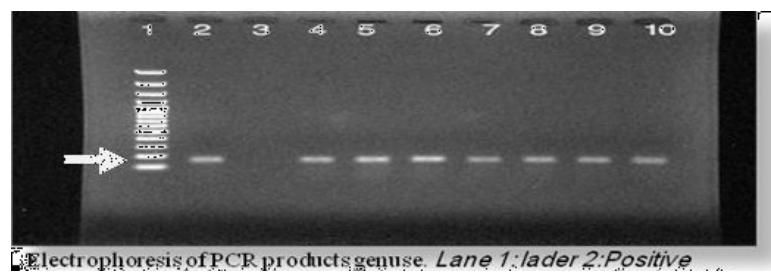

Figure 1a. Genus PCR. 


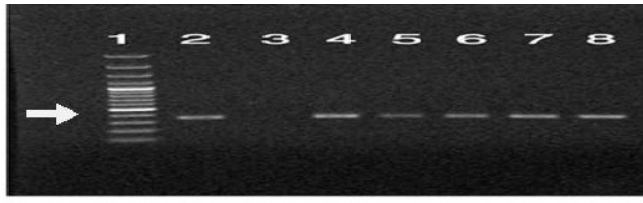

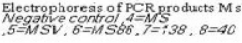

Figure 1b. MS PCR

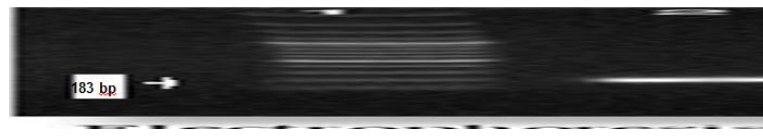

Figure 1c. MG PCR.

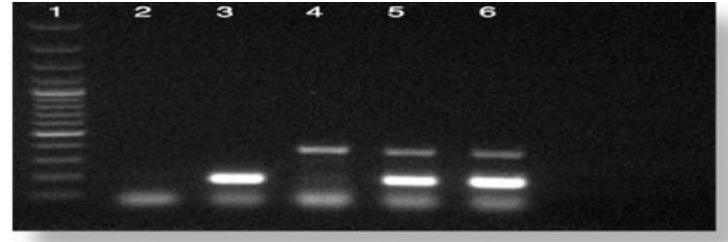

Electrophoresis of Duplex PCR products. M g-MS. Lane 1: lader 2:Positive control, Lane 3: Negative control, 4-5:Fildes Samples

Figure 1d. Duplex PCR.

Table 1. PCR result.

\begin{tabular}{|c|c|c|c|c|}
\hline $\begin{array}{c}\text { Total } \\
\text { samples }\end{array}$ & $\begin{array}{c}\text { Positive genus } \\
\text { PCR }\end{array}$ & $\begin{array}{c}\text { Positive } \\
\text { MG PCR }\end{array}$ & $\begin{array}{c}\text { Positive MS } \\
\text { PCR }\end{array}$ & $\begin{array}{c}\text { Samples contain } \\
\text { MG and MS }\end{array}$ \\
\hline 60 & 20 & 7 & 7 & 3 \\
\hline
\end{tabular}

Table 2. Duplex PCR results.

\begin{tabular}{|c|c|c|c|}
\hline $\begin{array}{c}\text { Total } \\
\text { samples }\end{array}$ & $\begin{array}{c}\text { Number of } \\
\text { Samples with } \\
\text { positive MG } \\
\text { Duplex PCR }\end{array}$ & $\begin{array}{c}\text { Number of samples with } \\
\text { positive MS Duplex PCR }\end{array}$ & $\begin{array}{c}\text { Number of } \\
\text { samples with } \\
\text { positive MS/MS } \\
\text { Duplex PCR }\end{array}$ \\
\hline 20 & 7 & 5 & 3 \\
\hline
\end{tabular}

This technique uses single template which can be a genomic DNA along with two pair of forward and reverse primers to amplify specific regions within a template.

Another type of duplex PCR uses duplex templates and two pair primers that set in the same reaction tube. In this study this type of duplex PCR had been worked by using duplex templates (MG and MS) and two pair primers were used which set in the same reaction tube. From 14 samples that were positive in MS or MG by PCR, 3 samples were positive in MG-PCR and MS-PCR in same time and 2 samples of them were positive by duplex PCR.

\section{Discussion}

In this study, duplex PCR method was applied to document the involvement of MG and MS infection simultaneity in trachea and lungs, air sac samples taken from commercial broiler farms in Iran.
Molecular tests are the alternative methods instead of conventional culture and serological tests because the molecular tests are faster and more inexpensive [11]. Molecular tests result could provide less than a day, also these tests could identify dead and non-living bacteria through DNA amplification and these tests could separate genus and species of the bacteria from each other. PCR assay as a molecular test can be completed in one day by using mucosal samples without special transport requirements other than a container to prevent cross contamination between flock specimens [18]. It is important to note that PCR assays based on the $m g c 2$ gene of MG [17] or the $v l h A$ gene of MS are becoming more widely used for PCRs for MG and MS [19]. These genes have been reported suitable for Mycoplasma detection [20].

Many PCR methods have been developed for detection of MG routinely in most laboratories PCR is a valuable method for identify MG infected flocks. Now we have several general method including a PCR method that targets the $16 S$ rRNA gene and three newly development diagnostic PCR method that target surface protein genes $(m g c 2, L P$, gap $A)$. PCR methods based on the $m g c 2, L P$ and gapA only amplified DNA from MG. While the $16 S r R N A$ PCR method amplified DNA from MG and M. imitans. These two phylogenetically related avain Mycoplasmas had a high amount 16SrRNA gene and PCR primers that are targeted to this gene amplify both Mycoplasmas. Garcia et al. used five PCR methods evaluated for detection of MG infection in chicken. These PCR methods were able to detect the two vaccine strains and the R-challenge strain which indicate different PCR methods and primers.

Bencina et al. suggested that the polymorphisms in 5'end of the vlhA gene might be very useful for epidemiological analysis of MS isolates and it is of interest that the two strains from UK pheasants comprised a unique group [21]. The $v \operatorname{lh} A$ gene has considerable divergence at the 3 'end of the gene due to recombination with pseudogenes (presumably as a mechanism to evade the host immune response), but relative conservation at the 5'end. The 5' $v \operatorname{lh} A$ region is present in the MS genome as a single copy and does not change its sequence in clonal populations of MS. This observation is crucial to strain identification as downstream of this region the sequence can change even in clonal populations of MS and therefore it cannot be considered a conserved sequence that characterizes individual strains [22]. The test evaluated by Hong et al. combined PCR and sequencing of the PRR repeat region of the llh $A$ gene to detect and type MS strains without the need for isolation. However, it excluded the RIII region (positions 343/400), which Bencina et al. found very useful for sub typing MS strains. The PRR region is useful mainly due to insertions/ deletions and the RIII region is useful because of polymorphisms and our findings have confirmed this, as have those of Jeffery et al. who, by chance, designed a reverse primer almost identical to ours. Hammond et al. using published primers, detection of MS and strain identification using the $v l h A$ gene sequence was attempted of 21 MS strains examined, three could not be amplified, so a new reverse primer was designed with a target in the conserved region of the $v l h A$ gene. Further testing demonstrated that this PCR was equally or more sensitive than other PCR tests used to detect 
Citation: Malekhoseini G, Pourbakhsh SA, Homayounimehr AR, Zolfeghari MR, Ashtari A, Abtin AR. Simultaneous identification of Mycoplasma gallisepticum and Mycoplasma synoviae by duplex PCR assay. Immunol Case Rep 2017;1(1):12-16.

MS. Subsequent DNA sequence analysis of the PCR product based on percent similarity and evolutionary relationship appeared to be a useful tool for strain differentiation.

Jefferye et al. used oligonucleotide primers complementary to the single-copy conserved 59 end of the variable lipoprotein and haemagglutinin gene $(v \operatorname{lh} A)$, amplicons of $\sim 400 \mathrm{bp}$ were generated from 35 different MS strains/isolates from chickens and subjected to mutation scanning analysis and show that the PCR-based SSCP or HRM curve analyses of $v$ lhA provide high-resolution mutation detection tools for the detection and identification of MS strains. In particular, the HRM curve analysis is a rapid and effective technique which can be performed in a single test tube in less than 2 hours. primer presented.

In the present study the primer for the specific detection MS in the $350 \mathrm{bp}$ fragments of $v l h A$ gene were amplified from Jefferye et al. More recently, conventional PCR methods have been described for simultaneous detection of $\mathrm{MG}$ and MS. Sprygin et al. and Ben Abdel moumen, Mardassi et al. and Pang et al reported that, duplex PCR assay is a more rapid and sensitive and useful method than the PCR technique for the detection of MS and MG which is in agreement [23,24]. Sprygin et al. showed that the development and validation of a duplex real-time polymerase chain reaction (PCR) assay with an internal control using TaqMan-labelled probes for the detection of MG and MS (duplex MGMS PCR), duplex MG MS PCR with IC using Taq Man-labelled probes (MGMS assay) that target the $m g c 2$ gene for the detection of $\mathrm{MG}$ and the vlhA gene of MS. But this method need more time consuming and cost than the duplex PCR and the duplex PCR based on the $16 S$ rRNA gene for MG detection cannot be applied.

Mardassi et al. used developed a duplex PCR assay targeting the hemagglutinin multigene families, $v l h A$ and $p M G A$, of MS and $\mathrm{MG}$, to confirm the specificity of the amplification reaction; a nested PCR was performed by using inner primers. Pang et al. a multiplex PCR was developed and optimized to simultaneously detect 6 avian respiratory pathogens. Six sets of specific oligonucleotide primers for infections IBV, AIV, ILTV, NDV, MG, MS were used respiratory in the test. In this study achieved the better and stronger result than the previous studies, of the test. The primers which in used in this study were related to conserve region of $\mathrm{MG}$ and $\mathrm{MS}$ and the difference between of Tm in these pair primers was low. The result of this study was showed that duplex PCR was successful insist of the PCR to simultaneous identification of MG and MS and used mainly basis of conserved $v l h A$ and $16 S$ $r R N A$ genes. In the present study duplex PCR enables to distinguish all samples are distinguished by single PCR.

\section{Conclusion}

In conclusion, the result of this study was shown that duplex PCR is more rapid and inexpensive method than the single PCR for detection of MG and MS so duplex PCR can be an alternative method for PCR to detect MG and MS with each other. In the present study duplex PCR is more capable to identify MG than MS and bands of MG are stronger than bands of MS. This study suggested for better identification of MS, it could be changed in program or master mix.

Hong et al. declared that comparing $v \operatorname{lh} A$-PCR with 16SrRNAPCR and projected that in very early stage of infection the $16 \mathrm{~S}$ rRNA procedure was more sensitive than the $v l h A$ method and also it could be designed other primers to diagnose $\mathrm{MG}$ and MS based on $16 S r R N A$ gene.

\section{Acknowledgments}

We thank all the staff of the Mycoplasma reference laboratory, Razi Vaccine and Serum Research Institute, Karaj, Iran. This study was supported by a project of Razi Institute and Education and Research Deputy of Jihad-Agriculture Ministry with the grant No.2-18-18-87080.

\section{References}

1. Bradbury JM. Mycoplasma infections. In: Jordan, FTW and Pattison, $\mathrm{M}$ and Alexander, DJ and Faragher, Teds Poultry Diseases. WB Sau nders, London. 2001; 571.

2. Kleven SH. Mycoplasmas in the etiology of multifactorial respiratory disease. Ft Jult Science.1998; 77:1146-49.

3. Kleven SH. Mycoplasma synoviae infection. In: Saif YM, Barnes HJ, Fadly AM, et al, eds. Diseases of Poultry. Ames, Iowa: Iowa State University Press. 2003; 756-66.

4. Levisohn S, Kleven SH. Avian mycoplasmosis (Mycoplasma gallisepticum). Rev Sci Tech. 2000;19(2): 425-42.

5. Lockaby B, Hoerr FJ, Lauerman LH, et al. Pathogenicity of Mycoplasma synoviae in broiler chickens. Vet Pathol. 1998;35:178-90.

6. Boyle JS, Good RT, Morrow CJ. Detection of turkey pathogens Mycoplasma meleagridis and $\mathrm{M}$. iowae by amplification of the $16 \mathrm{~S}$ rRNA, J. Clin. Microbiol. 1995;33:1335-38.

7. Garcia M, Jackwood MW, Head MW, et al. Use of species-specific oligo nucleotide probes to detect Mycoplasma gallisepticum, M. synoviae, and M. iowae PCR amplification products, J. Vet. Diagn. Invest. 1996;8:56-63.

8. Lauerman LH, Hoerr FJ, Sharpton AR, et al. Development and application of a polymerase chain reaction assay for Mycoplasma synoviae, Avian Dis. 1994;37:829-34.

9. Bayatzadeh MA, Pourbakhsh SA, Homayounimehr A, et al. Phylogenetic analysis of Mycoplasma Synoviae isolated from commercial Iranian chicken farms compared with other GeneBank isolate sequences based on $16 \mathrm{~S}$ rRNA gene. J Avian Biol. 2013;6:233-38.

10. Garcia M, Jackwood MW, Levisohn S. et al. Detection of Mycoplasma gallisepticum, M. synoviae, and M. iowae by multi-species polymerase chain reaction and restriction fragment length polymorphism, Avian Dis.1995; 39:606-16.

11. Mardassi BB, Mohamed RB, Gueriri I, et al. Duplex PCR to differentiate between Mycoplasma synoviae and Mycoplasma gallisepticum on the basis of conserved 
species-specific sequences of their hemagglutinin genes, J. Clin. Microbiol. 2005;43:948-58.

12. Chamberlain JS, Gibbs RA, Ranier JE, et al. Deletion screening of the Duchenne muscular dystrophy locus via multiplex DNA amplification. Nucleic Acids Res. 1988;16:11141-56.

13. Sprygin AV, Andreychuk DB, Kolotilov AN, et al. Development of a duplex real-time TaqMan PCR assay with an internal control for the detection of Mycoplasma gallisepticum and Mycoplasma synoviae in clinical samples from commercial and backyard poultry, Avian Pathol. 2010;39(2):99-109.

14. Pourbakhsh SA, Shokri GR, Banani M, et al. Detection of Mycoplasma synoviae infection in broiler breeder farms of Tehran province using PCR and culture methods. Archives of Razi Institute. 2010;65(2):75-81.

15. Kojima A, Takahashi T, Kijima M, et al. Detection of Mycoplasma in avian live virus vaccines by polymerase chain reaction. Biologicals. 1997;25:365-71.

16. Jeffery N, Gasser RB, Steer PA, et al. Classification of Mycoplasma synoviae strains using single-strand conformation polymorphism and high-resolution meltingcurve analysis of the vlhA gene single copy region, Microbiology. 2007;153:2679-88.

17. Garcia M, Ikuta N, Levisohn S, et al. Evaluation and comparison of various PCRmethods for detection of Mycoplasma gallisepticum infection in chickens. Avian. Dis. 2005;49:125-32.

18. Kleven SH Mycoplasma synoviae infection. In: Saif YM, Barnes HJ, Fadly AM, et al, eds. Diseases of Poultry. Ames, Iowa: Iowa State University Press. 2008;756-766.
19. Hong Y, Garcia M, Leiting V, et al. Specific detection and typing of Mycoplasma synoviae strains in poultry with PCR and DNA sequence analysis targeting the hemagglutinin encoding gene vlhA., Avian Dis. 2004;48:606-16.

20. Hammond PP, Rami'rez, AS Morrow, et al. Development and evaluation of an improved diagnostic PCR for Mycoplasma synoviae using primers located in the haemagglutinin encoding gene vlhA and its value for strain typing. Vet Microbiol. 2009;136:61-68.

21. Bencina D, Drobnic-Valic M, Horvat S, et al. Molecular basis of the length variation in the N-terminal part of Mycoplasma synoviae hemagglutinin, FEMS Microbiol. Lett. 2001;203:115-23.

22. Noormohammadi AH, Markham PF, Kanci A, et al. A novel mechanism for control of antigenic variation in the haemagglutinin gene family of Mycoplasma Synoviae, Mol Microbiol. 2000;35:911-23.

23. Pang $Y$, Wang $H$, Girshick $T$, et al. Development and Application of a Multiplex Polymerase Chain Reaction for Avian Respiratory Agents, Avian Dis. 2002;46(3):691-99.

\section{*Correspondence to}

Pourbakhsh SA

Mycoplasma Reference Laboratory, Razi Vaccine and Serum Research Institute,

Karaj, Iran 